\title{
JPEB
}

Jurnal Penelitian Ekonomi dan Bisnis, 5 (1), 2020, Hal: 77 - 89

http://www.jpeb.dinus.ac.id

\section{PERAN INKUBATOR BISNIS DALAM MEMBANGUN STARTUP PADA PERGURUAN TINGGI}

\author{
Ninda Lutfiani ${ }^{1}$, Untung Rahardja ${ }^{2}$ dan Ita Sari Perbina Manik ${ }^{3^{*}}$ \\ 1,2,3 Program Studi Sistem Informasi, Fakultas Sains dan Teknologi, Universitas Raharja \\ Jalan Jendral Sudirman No. 40 Modern Cikokol, Tangerang, Indonesia \\ *Corresponding Email : ita.sari@raharja.info
}

Diterima: Desember 2019; Direvisi: Desember 2019; Diterbitkan Maret 2020

\begin{abstract}
Startups are sufficiently developed in Indonesia to become a trend in business incubators that include college or university students. This is due to the incubation concept and program offered to prospective entrepreneurs who have potential ideas in business. Thus, research was conducted to determine the role of business incubators in building startups in universities. But there are obstacles in developing startups, limited technology, leadership and management. The study was conducted at the Alphabet Incubator of Raharja University with a qualitative approach. The research method used is the method of observation and literature review by collecting data that aims to simplify the process. It can be seen how the government encourages business incubators in developing startups and introducing business through technology. The research objective is to increase innovation or creativity in developing successful new startups in higher education. Seen from students utilizing the facilities at the Alphabet Incubator to develop small businesses in the digital industry to increase workforce.
\end{abstract}

Keywords: Business Incubator; Startup; Innovation or Creativity

\begin{abstract}
ABSTRAK
Startup cukup berkembang di Indonesia sehingga menjadi trend dalam inkubator bisnis yang mencakup mahasiswa atau mahasiswi di perguruan tinggi. Hal ini disebabkan konsep dan program inkubasi yang ditawarkan kepada calon wirausaha yang mempunyai ide potensial dalam bisnis. Sehingga penelitian dilakukan untuk mengetahui peran inkubator bisnis dalam membangun startup pada perguruan tinggi. Namun terdapat kendala dalam mengembangkan startup, terbatasnya teknologi, kepemimpinan dan manajemen. Penelitian dilakukan di Alphabet Incubator Universitas Raharja dengan pendekatan kualitatif. Metode penelitian yang digunakan adalah metode observasi dan literature review dengan mengumpulkan data yang bertujuan untuk mempermudah proses pengerjaannya. Dapat dilihat bagaimana pemerintah mendorong inkubator bisnis dalam mengembangkan startup dan mengenalkan bisnis melalui teknologi. Tujuan penelitian untuk meningkatkan inovasi atau kreativitas dalam mengembangkan startup baru yang sukses di perguruan tinggi. Terlihat dari mahasiswa memanfaatkan fasilitas di Alphabet Incubator untuk mengembangkan usaha kecil dalam industri digital untuk peningkatan tenaga kerja.
\end{abstract}

Kata Kunci: Inkubator Bisnis; Startup; Inovasi atau Kreativitas 


\section{PENDAHULUAN}

Perguruan Tinggi adalah sebuah sarana yang akan dilanjutkan setelah selesai pendidikan menengah atas yang menuju ke pendidikan yang lebih tinggi yang mencakup program diploma, program sarjana, program magister, program doktor, dan program profesi, serta program spesialis, yang diselenggarakan oleh perguruan tinggi berdasarkan kebudayaan bangsa Indonesia. Dan juga terdapat tridarma didalamnya yang berupa pendidikan, penelitian dan pengabdian kepada masyarakat. Oleh sebab itu Menteri Riset Teknologi dan Pendidikan Tinggi (Menristekdikti) Mohamad Nasir mengatakan, perguruan tinggi memiliki riset serta membuat prototipe dan inovasi yang dapat diterapkan oleh industri yang berguna bagi masyarakat. Sehingga perguruan tinggi diwajibkan untuk memiliki sebuah inkubator bisnis teknologi atau disebut (IBT) yang sangat produktif dalam membangun atau memulai wirausaha atau perusahaan yang baru (startup) dengan berbasis teknologi. Peran IBT meliputi pendampingan dan pelayanan dengan mengacu pada Peraturan Presiden Nomor 27 Tahun 2013 tentang Inkubator Wirausaha dan Peraturan Menteri Koperasi dan UKM Nomor 24 Tahun 2015 tentang Norma, Standar, Prosedur, dan Kriteria (NSPK) Inkubator Wirausaha.

Karena Startup sendiri sangat bermanfaat apabila digabungkan dengan academians, business, maupun government atau disebut dengan triple helix. Agar perguruan tinggi dengan akreditasi A maupun B harus memiliki inkubasi dari dosen dan mahasiswa, sehingga hasil penelitian berupa sebuah inovasi dapat dipasarkan langsung kepada masyarakat. Kemenristekdikti telah memperkuat kelembagaan dengan membentuk 44 IBT dan mengembangkan 5 IBT baru di luar Pulau Jawa yang masih kekurangan. Inilah beberapa IBT yang menghasilkan perusahaan pemula terbaik: (1) Incubie Institut Pertanian Bogor (IPB), (2) Direktorat Inovasi dan Inkubasi Bisnis Universitas Indonesia (DIIB UI), (3) Lembaga Penelitian dan Pengabdian kepada Masyarakat Universitas Negeri Yogyakarta (LPPM UNY), (4) Skystar Venture Universitas Multimedia Nusantara (UMN), (5) Inkubator Wirausaha Inovasi Jawa Tengah (Innov Jateng), (6) Maleo Techno Centre. (Ristekdikti, 2018)

Dan diketahui sejak tahun 2016, Kementerian Riset, Teknologi, dan Pendidikan Tinggi mengupayakan untuk menumbuhkan startup kampus lewat program "CPPBT". Sudah empat tahun terakhir Kemenristekdikti membina dan memberi fasilitas bagi calon PPBT dari setiap perguruan tinggi dengan jumlah calon 558 yang berasal dari seluruh wilayah yang terdapat di indonesia tanpa terkecuali. Jumlah yang didapat sebanyak 558 calon CPPBT tersebut ternyata hanya dapat lolos ke PPBT sebanyak 59 orang dengan persentase $10,57 \%$. Karena masih rendahnya CPPBT yang lolos ke PPBT. Maka tahun ini akan dilaksanakan Kegiatan CPPBT yang akan diselenggarakan pada tanggal 8-10 April 2019 dan diikuti oleh 132 peserta dari 70 Perguruan Tinggi yang tersebar hampir dari Sabang sampai Merauke. Agenda kegiatan selama CPPBT ini meliputi seminar, workshop, inspirational talk dan success story dari Calon PPBT yang berhasil naik ke kelas Program Perusahaan Pemula Berbasis Teknologi (PPBT) yang bertujuan untuk mengencangkan minat mahasiswa dalam membangun startup baru. Karena negara bisa dikatakan maju jika UMKMnya di atas 5\%, sedangkan Indonesia baru 1,6\%. "Ini masih jauh dari yang kita harapkan". ( KOMPAS.com 2019)

Diketahui startup merupakan bentuk inkubator yang berbasis dengan teknologi atau disebut juga dengan dunia digital. Negara Indonesia masuk dalam euforia 'startup' dimana terdapat para entrepreneur muda menciptakan bisnis yang berbau teknologi (startup) dengan memiliki inovasi dan kreatifitas dalam memanfaatkan teknologi tanpa batas. Karena startup sendiri merupakan perusahaan yang menggunakan teknologi dan web atau sering disebut dengan perusahaan yang berbasis teknologi dan online. Startup dapat digolongkan menjadi tiga di indonesia dengan mempunyai daya tarik dan kemudahan tersendiri dalam membuka usaha. Namun terdapat kendala dalam menjalankan bisnis startup tersebut, salah satunya adalah penggunaan dan pemanfaatan teknologi pada startup. 
Untuk mengembangkan startup baru agar terus berkembang, maka terdapat beberapa stakeholder industri digital dari operator telekomunikasi dan investor melakukan kerja sama dalam membangun berbagai kegiatan inkubasi serta akselerasi. Ada dasar dalam membentuk mahasiswa menjadi wirausaha pemula dalam membentuk kreativitas seperti: (1) tipe kreativitas dapat menerima pandangan dalam zaman sekarang, (2) tipe kreativitas dalam menolak pandangan sekarang dengan mengubahnya dan ke (3) tipe kreativitas yang ini yaitu dapat mensintesiskan pandangan atau paradigma sekarang (Pudianti dkk, 2018). Dengan adanya kegiatan inkubasi tersebut dapat mempengaruhi industri digital di indonesia dengan memanfaatkan inovasi dan kreativitas para pengusaha baru dalam mengembangkan bisnisnya.

Dari data diatas dapat dilihat bahwa inkubator bisnis sangat diharapkan oleh pemerintah dalam membangun startup pada perguruan tinggi, terutama Perguruan Tinggi Raharja. Di Universitas Raharja terdapat lembaga inkubator bisnis yaitu Alphabet Incubator (AI). Alphabet Incubator merupakan fasilitas baru yang diberikan Universitas Raharja untuk Dosen dan Mahasiswanya. Karena Alphabet Incubator (AI) merupakan sebuah aplikasi dengan pengendalian pusat berupa penelitian yang membangun sebuah startup baru dengan berbasis Corporate CreativePreneur. Dalam membangun aplikasi tersebut digunakan blockchain management system (BMS). Fungsi dari Alphabet Incubator tersebut sebagai tempat sharing hasil sebuah penelitian antara dosen dan mahasiswa. Dengan adanya kolaborasi antar mahasiswa dengan dosen atau mahasiswa dengan mahasiswa bertujuan untuk menumbuhkan jiwa bersaing atau kompetensi dalam membentuk ekonomi kreatif dengan mengembangkan dan meningkatkan UMKM dari program Pemerintah.

Lembaga inkubator bisnis yang terdapat Perguruan Tinggi seperti di Universitas Raharja memberikan pelayanan dalam membangun startup seperti memberikan konsep dengan fasilitas yang unik dan nyaman di Alphabet Incubator. Di dalam ruangan AI terdapat berupa kursi dan meja yang tertata rapi dengan desain seperti cafe. Sehingga dalam melakukan pembelajaran dan melakukan penelitian berlangsung tidak merasa bosan dan jenuh.

\section{A

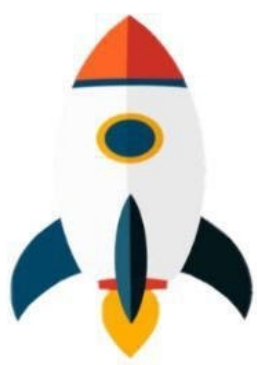 \\ Alphabet Incubator \\ Gambar 1. Logo alphabet Incubator}

\section{TINJAUAN PUSTAKA \\ Model Bisnis}

Dalam inkubator bisnis tentunya butuh sebuah pengembangan berupa model bisnis yang bertujuan untuk menarik daya saing atau kompetensi dalam wirausaha terhadap mahasiswa (Hamdan, 2013). Menurut M. Lahandi dan Maulidian (2019) dalam inkubator bisnis Universitas Trilogi mempunyai slogan yang disebut teknopreneur, kolaborasi dan kemandirian dengan mempunyai tujuan dalam mengembangkan bisnis para pengusaha baru (tenant) dibawah pendampingannya. 


\section{Bentuk Program Dalam Bisnis}

Dengan model bisnis yang ada tentunya dibutuhkan program bisnis. Program program yang diberikan kepada mahasiswa untuk mengembangkan jiwa kewirausahaan yaitu dengan cara memberi pembinaan kepada mahasiswa dalam menjalankan bisnisnya untuk dapat menghasilkan produk atau jasa yang dapat dijual secara online maupun offline yang dapat diterima dimasyarakat dan berkembang. Di Universitas sendiri bentuk program yang ditawarkan banyak jenisnya seperti memberikan paket terpadu yang didalamnya terdapat fasilitas berupa kantor, laboratorium dan juga terdapat fasilitas berupa pelatihan terhadap tenan agar menjadi wirausaha yang sukses dan tangguh (Budiyanto, dkk 2017). Menurut Alimudin (2015) Kewirausahaan adalah suatu proses pembelajaran yang dapat membangun karakter mahasiswa dalam wirausaha, karena mahasiswa dapat berani dalam mengambil suatu risiko, dapat melihat peluang pada masa yang akan datang dana dapat menciptakan produk yang terbaru sehingga dapat memberi nilai bagi konsumen sehingga produk yang dihasilkan berbeda dan mempunyai ciri khas.

\section{Modal Pendampingan Usaha.}

Rofieq et. al. (2018) menyampaikan pendapat Modal adalah salah satu bentuk yang diperlukan UMKM dalam bidang kerajinan dalam proses terbentuknya Startup yang berkembang dan sukses sehingga dibutuhkan sebuah model pendampingan yang sesuai pada Fashion usaha tersebut. Dalam wirausaha yang dilakukan di Kecamatan Cibungbulang melakukan program inkubator wirausaha sosial yang melakukan penerapan dengan konsep wirausaha yang berkembang di masyarakat dengan mendirikan sebuah forum pos daya dengan tujuan agar bentuk program yang diberikan dapat berjalan dengan baik (Saleh dan Sehabudin, 2015).

Beberapa penelitian terdahulu yang terkait mengenai inkubator bisnis memberikan hasil sebagai berikut:

Pada kalangan mahasiswa dibutuhkan strategi untuk menjalankan inkubator bisnis, strategi yang dibutuhkan melalui metode evaluasi, karena metode ini sangat mudah dipahami mahasiswa dalam perkuliahan yang dapat menjamin tercapainya pembelajaran kewirausahaan (Arasy 2015). Dalam perkembangannya Perguruan tinggi harus dapat melihat bahwa faktor dalam mengembangkan usaha yang berbasis teknologi merupakan lembaga yang siap untuk dapat mendorong dan memberi layanan serta pendampingan terhadap mahasiswa dalam mengembangkan Startup tersebut, lembaga tersebut disebut dengan inkubator bisnis (Jaya, dkk 2017)

Startup adalah salah satu inkubator bisnis yang berjalan pada UMKM kerajinan, Oleh karena itu UMKM sendiri membutuhkan model pendampingan yang berguna untuk UMKM dalam menjalankan usahanya (Rofieq, dkk 2018). Banyak cara yang dilakukan untuk mengembangkan Startup tersebut yang bertujuan untuk meningkatkan UMKM di Indonesia dan untuk meningkatkan kreativitas atau inovasi dari para mahasiswa (Rofie, dkk 2018). Di Dalam inkubator bisnis pasti terdapat teknologi dalam perusahaan maupun lembaga untuk memberi pelayanan dalam membina masyarakat dalam bisnis yang bertujuan agar UMKM terorganisir sehingga menjadi perusahaan yang sukses (Nurdianto 2019).

Dilihat bahwa inkubator bisnis adalah sebuah lembaga yang berfungsi dalam menyediakan fasilitas seperti manajemen dan teknologi yang bertujuan untuk meningkatkan usaha kecil, menengah dalam produk yang dibuat. Menurut (Maharani 2015). Pengangguran adalah permasalahan yang kerap terjadi pada masyarakat di berbagai daerah seperti di Kota Sidoarjo, dengan adanya inkubator dan teknologi di dalamnya menjadi harapan masyarakat agar terbentuk UMKM yang berguna untuk mengurangi pengangguran di tengah masyarakat (Nurdianto 2019). 
Dalam inkubator bisnis terdapat proses inkubasi yang berperan untuk melakukan pendampingan terhadap tenant dengan tujuan agar tenant dapat menyelesaikan masalahnya dengan baik sehingga jiwa kompetensi atau bersaing dalam usaha dapat bertahan dan berembang pesat (Siregar, dkk 2019). Perguruan tinggi merupakan tempat pembelajaran yang baik dalam berwirausaha dengan memberi inovasi untuk dapat membangun usaha sendiri. Karena dengan adanya pembelajaran ini diharapkan tumbuhnya jiwa kompetensi kewirausahaan untuk berani memimpin, mandiri, dan mampu bersaing dengan kreativitas serta inovasi yang dimiliki oleh mahsiswa tersebut (Kurniasari dan Putra 2018)

Berdasarkan literatur diatas dapat disimpulkan bahwa dalam inkubator bisnis tentunya membutuhkan suatu proses inkubasi yang bertujuan untuk melakukan pendampingan terhadap calon tenant baik di perguruan tinggi maupun pada masyarakat yang mempunyai UMKM. Namun dibutuhkan strategi untuk menjalankan inkubator bisnis tersebut. Seperti menyediakan fasilitas berupa pendampingan teknologi, manajemen dan modal. Dengan begitu para tenant dapat menghasilkan produk yang bagus dari inovasi dan kreativitas yang dimiliki sehingga mampu mandiri dan dapat melihat peluang dalam membuka usaha dengan memanfaatkan teknologi dalam melakukan pemasarannya.

\section{METODE PENELITIAN}

Diketahui penelitian tersebut menggunakan metode observasi dan literature review. Dimana observasi yang akan dilakukan dengan cara mengamati dan melakukan proses pembelajaran atau sharing penelitian yang dihasilkan oleh mahasiswa di Alphabet Incubator Universitas Raharja.

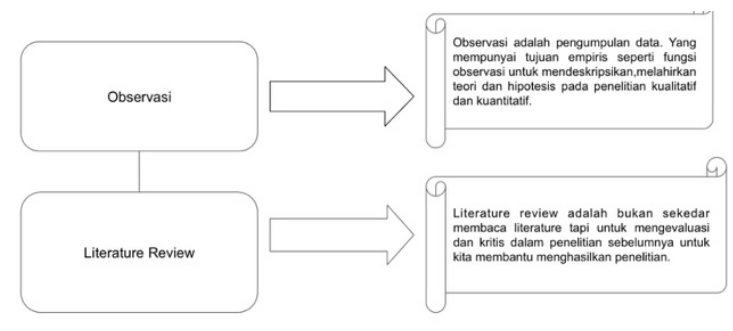

\section{Gambar 2. Alur Penelitian}

\section{HASIL DAN PEMBAHASAN \\ Inkubator Bisnis.}

Dapat diketahui inkubator bisnis adalah merupakan lembaga intermediasi yang bertujuan untuk menumbuh kembangkan wirausaha pemula berbasis teknologi selama periode waktu tertentu. Dan lembaga inkubator bisnis yang berada di bawah pengelolaan perguruan tinggi menggunakan konsep link and match. Putra (2017) berpendapat konsep link and match merupakan salah satu bentuk pembelajaran berupa pendampingan dengan cara work based learning dengan mempraktikan pekerjaan dalam industri.

\section{Perguruan Tingi}

Perguruan tinggi yang mempunyai lembaga inkubator bisnis berpengaruh secara pada peningkatan sistem pembelajaran, persepsi, aktivitas dan efektivitas dari organisasi dan penciptaan yang sinergi serta pemahaman Tri Dharma Perguruan Tinggi secara integral. Dalam perkembangannya Perguruan tinggi harus dapat melihat bahwa faktor dalam mengembangkan usaha yang berbasis teknologi merupakan lembaga yang siap untuk dapat mendorong dan memberi layanan serta pendampingan terhadap mahasiswa dalam mengembangkan Startup, lembaga tersebut disebut dengan inkubator bisnis (Jaya, dkk 2017). 
Dalam lembaga inkubator bisnis yang berada dibawah pengelolaan Perguruan Tinggi memberi empat kebutuhan dalam kinerja pada era globalisasi sekarang atau yang akan datang: (1) kebutuhan akan pekerjaan yang menantang (challenging) yaitu pekerjaan yang tidak mudah diselesaikan tapi dapat diselesaikan dengan baik sehingga pekerjaan tersebut dapat mencapai sebuah tujuan, (2) kebutuhan pekerjaan dengan lingkungan yang kondusif, yaitu lingkungan yang mendukung sumber daya manusia dan lingkungan sumber daya manusia, (3) kebutuhan pekerjaan yang mempunyai keahlian atau kemampuan dalam bekerja, dan ke (4) kebutuhan pemberdayaan jiwa entrepreneur, yaitu memiliki ciri: pencapaian tujuan dari organisasi, terbukanya akses sumber daya manusia, mempunyai motivasi kerja tinggi, inovatif, kreatif dan lainnya.

Inkubator bisnis juga memberi pelaksanaan program pelatihan dan pendampingan terhadap perguruan tinggi dengan melakukan cara seperti classical, studi kasus, diskusi dan simulasi yang membuat para mahasiswa lebih mudah dan aktif dalam mengikuti pelatihan tersebut untuk menambah pengalaman dan kemampuan dalam jiwa wirausaha. Dan ada lima program yang diberikan seperti: (1) pembinaan, yaitu untuk dapat mengatasi memecahkan masalah yang akan dihadapi dengan memberi konsultasi, (2) melakukan riset pasar, yaitu untuk mengetahui peluang dalam penjualan produk dan pengembangannya, (3) kerjasama antar lembaga, yaitu proses saling membutuhkan yang menghasilkan nilai tambah dan ekonomi, (4) pembentukan unit bisnis, yaitu program yang melakukan pendampingan dalam mengarahkan proses berjalannya unit usaha yang dibentuk dan ke (5) pengembangan, yaitu proses mengembangkan dalam produk, pasar dan manajerial dalam wirausaha.

Terdapat tujuh contoh inkubator dalam Pengembangan UMKM.
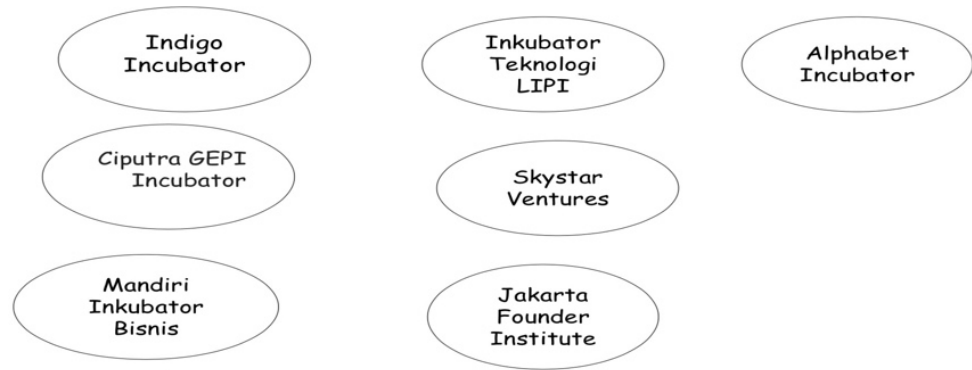

\section{Gambar 3. Program dari Inkubator}

Konsep yang diberikan dari program inkubator dan tahap calon tenan tersebut memiliki tahapan:

1. Indigo Incubator
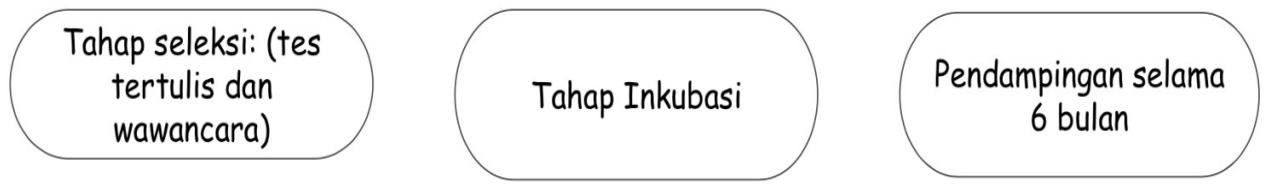

Gambar 4. Tahapan Indigo Incubator

Dalam proses inkubasi peserta yang lolos akan diberi suntikan dana sebesar Rp. 250 juta dan berupa dukungan seperti memberi fasilitas. 
Ninda Lutfiani, Untung Rahardja dan Ita Sari Perbina Manik : Peran Inkubator Bisnis Dalam Membangun Startup Pada Perguruan Tinggi

2. Ciputra GEPI Incubator
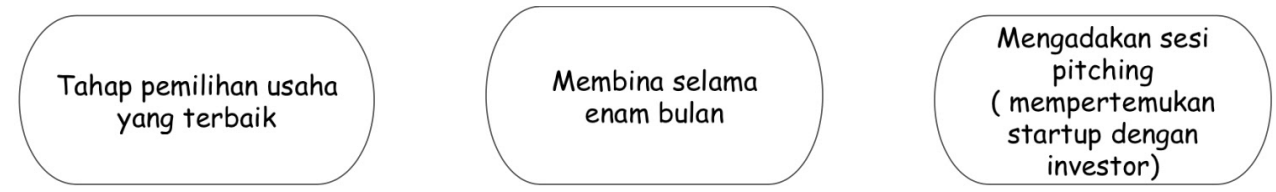

Gambar 5. Tahapan Ciputra GEPI Incubator

Disini Ciputra GEPI Incubator juga memberi fasilitas dan layanan berupa senilai Rp. 100 juta serta enam bulan coworking space di gedung perkantoran, dengan jam kerja yang fleksibel, bantuan hukum, serta berbagai workshop yang difasilitasi oleh para ahli dalam masing-masing industri.

3. Mandiri Inkubator Bisnis
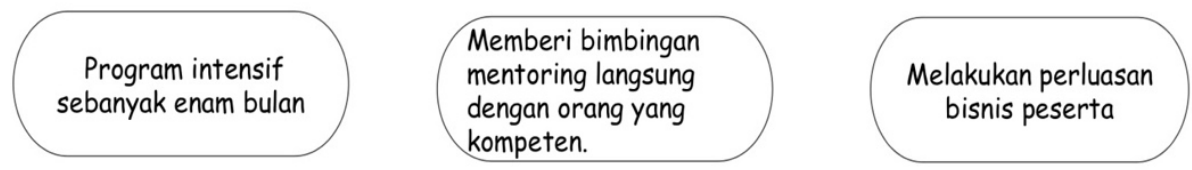

\section{Gambar 6. Tahapan Mandiri Inkubator Bisnis}

Disini Mandiri Inkubator Bisnis memberikan fasilitas kepada peserta berupa sebuah kombinasi workshop dan praktik secara langsung, memberi akses ke jaringan Bank Mandiri dan memberikan sebuah tempat untuk bekerja sama.

4. Inkubator Teknologi LIPI

Biasa para calon tenant memberikan sebuah idea proposal bisnis yang terdapat dalam empat kategori klasifikasi yaitu:
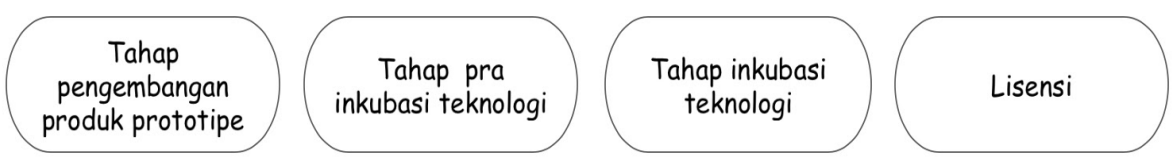

\section{Gambar 7. Tahapan Inkubator Teknologi LIPI}

Lembaga tersebut memberikan fasilitas berupa tempat sewa kantor yang terjangkau, memberi bengkel produksi, ruang pertemuan, layanan promosi, dan pendampingan rutin kepada tenant.

5. Skystar Ventures
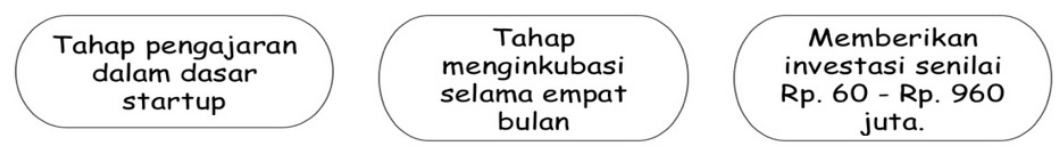

Gambar 8. Tahapan Skystar Ventures

Dan para peserta mendapatkan fasilitas berupa network dan fasilitas co-working di New Media Tower milik Universitas Multimedia Nusantara di Tangerang.

6. Jakarta Founder Institute

Melakukan biaya pendaftaran bagi calon peserta sebesar US $\$ 25$ bagi yang tertarik atau berminat dalam mengikuti program inkubasi tersebut dan startup yang lolos atau terpilih dikenakan biaya kursus sebesar US\$500. 


\section{Alphabet Incubator}

Lembaga yang terdapat di Universitas Raharja dengan memberikan pendampingan dan fasilitas berupa ruangan yang nyaman serta pembinaan dari Dosen kepada mahasiswa dalam pembelajaran. Dalam terbentuk Inkubator pasti terdapat sumber dana yang diberikan oleh IBT: (1) Dana internal Universitas (IDR 500jt per tahun, (2) Dana hibah dari pemerintah (IDR 500jt per tahun), (3) Dana CSR BUMN dan perusahaan swasta (IDR 150jt per tahun) dan (4) Royalti \& share saham dari anchor tenant (IDR 50jt per tahun).

Dari dana yang tertera diatas sudah terlihat pemerintah selalu mendorong perguruan tinggi agar dapat mempunyai sebuah inkubator bisnis sendiri agar diinkubasikan terhadap para dosen dan mahasiswa dengan memberikan pendampingan, pelayanan dan fasilitas dengan tujuan membangun startup yang berkembang dan sukses sehingga startup tersebut dapat bertahan dan menumbuhkan ekonomi kreatif di tengah masyarakat, dan mampu membuka lapangan pekerjaan tentunya.

\section{Startup}

Startup adalah sebuah kata yang berasal dari bahasa Inggris, sebuah tindakan untuk memulai atau membuka usaha atau bisnis baru. Dan menurut Wikipedia arti startup adalah sebuah perusahaan yang masih baru atau belum lama beroperasi. Perusahaan startup merupakan perusahaan yang baru dibangun dan masih butuh dikembangkan. Tapi dapat diartikan juga startup adalah perusahaan yang berbasis teknologi atau web dan sering disebut perusahaan online.

Startup sendiri mempunyai 6 ciri atau karakteristik seperti: (1) Usia dari perusahaan kurang lebih dari 3 tahun, (2) Jumlah pegawai dalam perusahaan tersebut kurang lebih 20 orang, (3) Pendapatan yang diterima \$100.000/tahun, (4) Perusahaan tersebut masih tahap berkembang, (5) Perusahaan tersebut beroperasi dalam bidang teknologi dengan beroperasi dan (6) Produk yang dibuat berupa aplikasi digital.

Dalam perkembangannya startup di Indonesia meningkat dari hasil riset tahun 2013 mencapai 70 juta orang dari penggunaan internet di Indonesia. Sekarang ini terdapat setidaknya lebih dari 1500 Startup lokal yang ada di Indonesia. Diketahui sampai sekarang penggunaan internet di Indonesia meningkat dan lebih dari 70 juta orang dan dapat memengaruhi perkembangan startup dengan pesat pada industri digital.

Menurut Rama Mamuaya CEO dailysocial.net, Startup di Indonesia digolongkan dalam tiga kelompok yaitu;

1. Startup pencipta game

2. Startup aplikasi edukasi

3. Startup perdagangan seperti e-commerce dan informasi.

Dengan berkembangnya teknologi digital perusahaan dapat memanfaatkan kemudahan tersebut dalam melakukan transaksi jual beli terhadap customer dengan menggunakan media sosial sehingga dalam melakukan pengenalan produk menjadi lebih cepat dan praktis.

Di Indonesia sekarang ini telah banyak berdiri komunitas founder Startup, yaitu: (1) Bandung Digital Valley (bandungdigitalvalley.com) (2) Jogja Digital Valley (bandungdigitalvalley.com), (3) Ikitas (www.ikitas.com), inkubator bisnis di Semarang, (4) Station (stasion.org), wadah bagi Startup lokal kota Malang, dan masih banyak lagi yang lainnya.

Faktor-faktor yang mempengaruhi berkembang nya startup "menurut techinasia" tertera dalam grafik di bawah ini. 


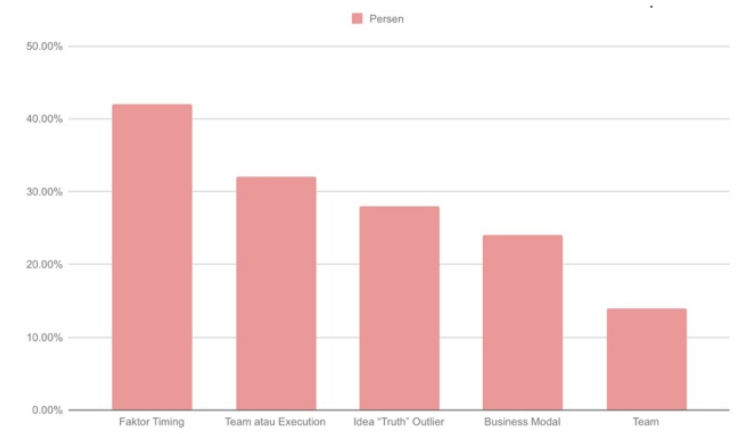

Gambar 9. Grafik Berkembngnya Startup

Keterangan:

1. Sebesar $42 \%$ dipengaruhi faktor timing.

2. Sebesar $32 \%$ dipengaruhi team atau execution.

3. Sebesar $28 \%$ dipengaruhi idea "truth" outlier.

4. Sebesar $24 \%$ dipengaruhi business.

5. Sebesar $14 \%$ dipengaruhi team.

Dari data diatas terlihat waktu sangat berperan dalam berkembangnya startup dan team dalam melakukan kolaborasi mengenai ide. Sehingga para founder dan investor dapat melakukan sharing dengan team tersebut. Sehingga meningkatnya keinginan untuk berkompetisi antar team founder komunitas. Terlihat banyak faktor yang membangun atau mengembangkan perusahaan Startup. Dengan berkembangnya teknologi ada 4 startup unicorn yang berasal dari Indonesia, yaitu Traveloka, Tokopedia, Bukalapak \& GO-JEK.

Data dari Tech In Asia menunjukan jika pada kuartal 2 tahun 2017, startup yang mendominasi di Indonesia berasal dari industri E-Commerce \& Fintech. Namun ada beberapa indikator penghambat berkembang nya start up yaitu:

1. Komunikasi yang kurang baik terhadap sebuah produk yang ingin dipasarkan namun startup gagal untuk menampung feedback dari target pengguna tersebut.

2. Masih kurangnya relasi antar founder dengan pelanggan atau disebut pelayanan yang tidak maksimal.

3. Sulit dalam mendapatkan sebuah team yang solid dalam mengembangkan startup.

4. Kurangnya dalam hal kepemimpinan founder terhadap usaha yang dijalankan.

5. Sulit dalam melakukan validasi.

Dan dari presentation IBT Petra 3 Mei 2019, dapat dilihat bahwa inkubator bisnis teknologi (IBT) memiliki tujuan untuk: (1) Mempunyai 20 calon startup dengan 10 Startup yang dapat di bimbing setiap tahunya, (2) Sebanyak tiga anggota diluluskan yang memberikan dampak sosial dan memiliki omset IDR 300jt per tahun, (3) Mengikuti 2 event promosi yang diadakan nasional dan 1 event promosi internasional per tahun.

Menurut Rofieq dan Farida (2018) Banyak cara yang dapat dilakukan untuk mengembangkan Startup dengan tujuan meningkatkan UMKM di Indonesia dan meningkatkan kreativitas atau inovasi dari para mahasiswa dalam membangun ekonomi kreatif.

\section{Alphabet Incubator}

Alphabet Incubator merupakan fasilitas baru yang terdapat di Universitas Raharja. Alphabet Incubator (AI) merupakan sebuah aplikasi dengan pengendalian pusat berupa penelitian yang membangun sebuah startup baru dengan berbasis Corporate CreativePreneur yang merupakan bentuk dari IBT. Maksud dari Corporate CreativePreneur adalah sebuah 
pelaku kreativitas seseorang dalam membawa perubahan berupa ide atau inovasi baru untuk dapat menghasilkan karya yang besar yang dapat didapat di perguruan tinggi melalui sebuah pendampingan.

Dan ada 8 karakteristik yang dimiliki oleh seorang creativepreneur, yaitu; bold moves, innovative, hybrid skill, tech-savvy, desain-awaare, collaboration, short planer dan doer. Dalam membangun aplikasi tersebut digunakan blockchain management system (BMS). Fungsi dari Alphabet Incubator tersebut sebagai tempat sharing hasil sebuah penelitian antara dosen dan mahasiswa seperti pembuatan jurnal dan pengajuan hibah. Dengan adanya kolaborasi tersebut antar mahasiswa dengan dosen atau mahasiswa dengan mahasiswa dapat menumbuhkan jiwa untuk bersaing atau kompetensi. Program dari pemerintah dalam membentuk ekonomi kreatif dalam mengngembangkan dan meningkatkan UMKM dapat berjalan karena adanya kolaborasi tersebut dan dapat melahirkan startup baru yang dapat menghadi era disrupsi.

Sehingga mahasiswa bisa memanfaatkan teknologi dari fasilitas yang ada untuk lebih meningkat inovasi atau idea kreatif yang dimiliki untuk kedepannya. Lembaga inkubator bisnis yang terdapat Perguruan Tinggi seperti di Universitas Raharja memberikan pelayanan dalam membangun startup seperti memberikan konsep dengan fasilitas yang unik dan nyaman di Alphabet Incubator. Di dalam ruangan AI terdapat berupa kursi dan meja yang tertata rapi dengan desain seperti cafe. Sehingga dalam melakukan pembelajaran dan melakukan penelitian berlangsung tidak merasa bosan dan jenuh. Walaupun begitu perguruan tinggi dapat dengan melakukan kerjasama terhadap mahasiswa untuk dapat menjaga ruangan Alphabet Incubator dan termasuk kedalam sebuah pengabdian tridharma dalam perguruan tinggi.

\section{Kegiatan Dalam Alphabet Incubator}

Di Alphabet Incubator banyak yang dapat dilakukan mahasiswa tentunya, seperti melakukan sharing mengenai jurnal, hibah dan proposal cbbpt. Dalam melakukan sharing hasil penelitian seperti jurnal. Mahasiswa tersebut mempersentasikan hasil karya yang sudah ditulis didepan pembimbingnya dengan membaca dan menjelaskan poin-poin didalamnya. Sehingga dosen pembimbing tersebut dapat memberi saran dan mengevaluasi hasil jurnal yang telah ditulis oleh mahasiswa tersebut. Seperti halnya sekarang Alphabet Incubator tersebut mempunyai media sosial youtube dan instagram.

Seperti dijelaskan tadi dalam mahsiswa melakukan persentasi karyanya dapat diihat dichannel youtube Alphabet Incubator, dengan ini mahasiswa tersebut melatih langsung mental dirinya terhadap orang sekitar diruangan tersebut, karena proses dalam melakukan persenatsi mengenai jurnal di rekam atau di live secara langsung dari youtube channel incubator yang diberi nama Magics Channel di Universitas Raharja. Dengan ini para mahasiswa yang lain juga mengetaui dan merasakan manfaat dari Alphabet Incubator tersebut untuk mendorong proses pembelejaran dan dapat dinikmati oleh mahasiwa maupun dosen di perguruan tinggi.

\section{Konsep Ruangan Alphabet Incubator}

Dalam ruangan Alphabet Incubator (AI) diberi konsep dengan desain Orchestra yang membuat ruangan tersebut sangat kekinian dan modern. Disetiap dinding diberi gambar bintang, planet dan gambar lainnya yang membuat merasa nyaman didalamnya karena tidak monoton dengan dinding yang bernuansa polos tanpa gambar. Tidak lupa dengan meja panjang dan kursi yang berjajar rapi menambah rasa nyaman tentunya dan ruangan yang sejuk. Disudut ruang juga diberi kursi dengan nuansa seperti kafe sehingga saat melakukan kegiatan atau diskusi mengenai penelitian merasa santai. 


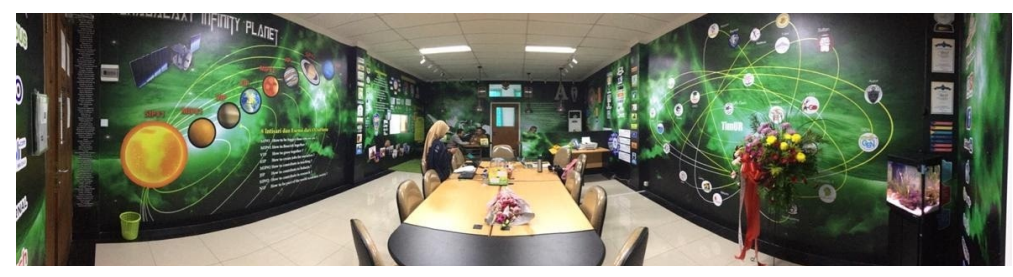

Gambar 10. Ruangan Alphabet Incubator

Sudah terlihat bahwa peran dari incubator dalam melakukan proses inkubasi ke perguruan tinggi sangat bermanfaat. Terlihat dari pendampingan yang diberikan perguruan tinggi kepada mahasiswa dalam segi fasilitas berupa rungan Alphabet Incubator yang begitu nyaman dan dapat mempengaruhi mahasiwa lebih semangat dan lebih fokus untuk menyelesaikan penelitiannya. Dibalik itu semua anggaran yang dikeluarkan sebesar 2,4 Miliar angka yang fantastis bukan. Alphabet Incubator merupakan salah bentuk contoh dalam membangun inkubator bisnis startup terhadap revolusi industri 4.0 yang selama ini terhambat dari segi akurasi data, proses administrasi yang memakan waktu lama, dan tidak terintegrasi dari segi pelaksanaan catur dharma yang terdapat di perguruan tinggi. Dalam melakukan penelitian tersebut dilakukan dengan observasi dan literatur review dengan pendekatan kualitatif.

Tujuan penelitian tersebut adalah untuk mengetahui peran yang sudah diberikan inkubator bisnis untuk membangun startup pada perguruan tinggi dalam mengetahui apa saja yang sudah didapatkan mahasiswa dari program yang diberikannya dan fasilitas apa yang sudah terbentuk dari adanya program inkubator tersebut terhadap perguruan tinggi dan mahasiswa dapat membangun startup baru untuk meningkatkan industri teknologi dan membuka lapangan pekerjaan di indonesia.

Dengan ini pertumbuhan UMKM di Indonesia dapat mencapai diatas 5\% kedepannya, dari adanya pendampingan inkubator bisnis tersebut terhadap perguruan tinggi diharapkan mahasiswa yang sudah mempunyai bekal pengalaman dan pembelajaran mengenai bisnis dapat membuat startup baru yang berkembang dan sukses tentunya sehingga dapat bertahan dan mencapai pasar internasional.

\section{SIMPULAN}

Dari penelitian tersebut Inkubator bisnis sangat berperan penting bagi Perguruan Tinggi dalam mendorong kreativitas dan inovasi mahasiswa dalam berwirausaha. Dengan adanya ini kinerja di Perguruan Tinggi dapat terlihat dalam mengembangkan startup yang berkaitan dengan Tridharma sebagai contoh pengabdian kepada masyarakat. Dalam Perguruan Tinggi memberikan konsep link and match yang bertujuan agar mahasiswa dapat nyaman dan mudah mengikuti pembelajaran dalam inkubator bisnis. Namun ada kendala proses dalam berjalannya inkubasi dalam mengembangkan startup pada perguruan tinggi seperti sumber daya manusia. Dalam penelitian tersebut memanfaatkan kreativitas dan inovasi mahasiswa berkembang pesat dari pengaruh inkubator bisnis dari program Alphabet Incubator di Universitas Raharja. Sehingga penelitian yang selanjutnya dapat menggunakan metode baru dan memudahkan penelitian untuk mengembangkan kreativitas dan inovasi dengan teknologi. Agar perkembangan inkubator bisnis startup lebih terkenal di kalangan mahasiswa dan peningkatan inkubator dalam memberi fasilitas dalam segi konsep dan inkubasi kepada para calon startup lebih memadai. 


\section{DAFTAR PUSTAKA}

Alimudin, Arasy. 2015. Strategi pengembangan minat wirausaha melalui proses pembelajaran. E-Jurnal Manajemen Kinerja. 1: 1-13.

Arip, Yusuf \& Wajdi, M Farid. 2019. Efektivitas Model Pembelajaran Berbasis Student Enterprise Dalam Rangka Meningkatkan Kompetensi Wirausaha Mahasiswa Di Universitas Muhammadiyah Ponorogo. Tesis. Surakarta: Universitas Muhammadiyah Surakarta.

Ashfihani, Ahmad. 2018. Peran Pimpinan FEBI Dalam Meningkatkan Motivasi Berwirausaha Bagi Mahasiswa Program Studi Ekonomi Syariah UIN Sunan Ampel Surabaya. Skripsi. Surabaya: UIN Sunan Ampel.

Baskoro, M Lahandi \& Maulidian, Maulidian. 2019. Pelatihan Instagram Marketing Untuk Tenant Inkubator Bisnis Trilogi. JURDIMAS. 2 (1): 19-26.

Budiyanto, Hery, Suprapto, Agus \& Poerwoningsih, Dina. 2017. Program Pengembangan Kewirausahaan Dalam Bentuk Inkubator Bisnis Di Perguruan Tinggi Bagi Mahasiswa Pemilik Usaha Pemula. Prosiding. Disajikan dalam Seminar Naisonal Sistem Informasi (SENASIF).

Dewi, Yovita Anggita. 2016. Inovasi Spesifik Lokasi untuk Inkubator Teknologi mendukung Pengembangan Ekonomi Lokal. Analisis Kebijakan Pertanian. 10 (4): 299-312.

Disas, Eka Prihatin. 2018. Link and Match sebagai Kebijakan Pendidikan Kejuruan. Jurnal Penelitian Pendidikan. 18: 231-242.

Edris, Mochamad, Handoyo, Ag Sunarno \& Lusianti, Dina. 2017. Kinerja UMKM Tenant Inkubator Bisnis Universitas Muria Kudus Berdasarkan Implementasi E-marketing. Prosiding. Disajikan dalam SNATIF.

Hakim, Lukmanul, Syarifuddin, Didin \& Iskandar, Iis. 2018. Membangun Inkubator Wirausaha Kepariwisataan di STP ARS Internasional. Jurnal Pengabdian Kepada Masyarakat. 1:1.

Hamdan, Hamdan. Model Inkubator Bisnis Untuk Menumbuhkan Kompetensi Kewirausahaan. Jurnal Penelitian Pendidikan. 13:1.

Jaya, Mardi Arya, Ferdiana, Ridi \& Fauziati, Silmi. 2017. Analisis Faktor Keberhasilan Startup Digital di Yogyakarta. Prosiding. Disajikan dalam SNATIF.

Kurniasari, Fita \& Putra, Eka Wira. 2018. Model Pembelajaran Industrial Incubator Based Learning (IIBL) Untuk Mengembangkan Jiwa Kewirausahaan Mahasiswa Universitas Muhammadiyah Pontianak. Pena Kreatif: Jurnal Pendidikan. 7: 53-59.

Mahani, Septiana Ayu Estri. 2015. Tinjauan Model Inkubator Bisnis Rintisan (Bisnis Start Up) Di Indonesia. Jurnal Manajemen dan Bisnis: Performa. 76-95.

Nurdianto, Alifian Bayu. 2018. Optimalisasi Wakaf Untuk Inkubator Bisnis Dan Teknologi Usaha Mikro Kecil Menengah (UMKM) Di Sidoarjo. ISTISMAR. 1: 43-49.

Pudianti, Anna, Herawati, Anita \& Purwaningsih, Anna. 2018. Faktor Kreativitas dalam Pengembangan Model Inkubator Bisnis di Era Digital. BISMA (Bisnis dan Manajemen). 10: $145-155$.

Putra, Ryan Aditya \& Sofyan, Herminanto. 2017. Partisipasi Industri Otomotif Dalam Implementasi Work Based Learning Di SMK Daerah Istimewa Yogyakarta. E-Jurnal Pendidikan Teknik Otomotif-S1. 19:1.

Rahardja, Untung, Lutfiani, Ninda \& Yolandari, Aulia. 2019. Penerapan Viewboard Informatif Pada Asosiasi Perguruan Tinggi Swasta Indonesia Dalam Era Industri 4.0. Technomedia Journal. 3: 224-234.

Raharja, Untung, Harahap, Eka Purnama \& Devi, Ririn Eka Cipta. 2018. Pengaruh Pelayanan dan Fasilitas pada Raharja Internet Cafe Terhadap Kegiatan Perkuliahan Pada Perguruan Tinggi. Jurnal Teknoinfo. 12: 60-65. 
Rofieq, Mochammad Rofieq, Permatasari, Ditya Permatasari \& Farida, Lailatul Farida. 2018. Model Pendampingan Umkm Bidang Kerajinan Menjadi Start-Up Sukses Di Kota Malang. Jurnal Pengabdian Kepada Masyarakat.3(2)

Salam, Rudi, Akhyar, Muhammad, Tayeb, Abd Muhaimin \& Niswaty, Risma. 2017. Peningkatan Kualitas Publikasi Ilmiah Mahasiswa dalam Menunjang Daya Saing Perguruan Tinggi. Jurnal Office. 3: 61-65.

Saleh, Amiruddin \& Sehabudin, Ujang. 2015. Pengembangan Program Inkubator Wirausaha Sosial di Kecamatan Cibungbulang, Kabupaten Bogor. Agrokreatif Jurnal Ilmiah Pengabdian kepada Masyarakat. 1: 88-95.

Saputra, Andy. 2015. Peran Inkubator Bisnis dalam Mengembangkan Digital Startup Lokal di Indonesia. Calyptra. 4: 1-24.

Saputra, Wawan \& Purnama, Bambang Eka. 2011. Pengembangan Multimedia Pembelajaran Interaktif Untuk Mata Kuliah Organisasi Komputer. Speed-Sentra Penelitian Engineering dan Edukasi. 4:2.

Setyawati, Christina Yanita. 2016. Dampak Mentoring Pada Keberhasilan Start-Up Business: Studi Kasus Pada Start-Up Business di Indonesia (Mentoring the Impact of Success of a Start-Up Business: A Case Study of a Start-Up Business in Indonesia).Jurnal Manajemen. 11: 290-310.

Siregar, Gustina, Andriany, Dewi \& Bismala, Lila. 2019. Program Inkubasi Bagi Tenant Inwall Di Pusat Kewirausahaan, Inovasi dan Inkubator Bisnis Universitas Muhammadiyah Sumatera Utara. Prosiding. Disajikan dalam Seminar Nasional Kewirausahaan, Universitas Muhammadiyah Sumatera Utara.

Soba, Heriyanto S, Hasbullah, Rokhani \& Nuryartono, Nunung. 2018. Strategi Pengembangan Inkubator Bisnis Sebagai Lembaga Pendampingan Perusahaan Pemula: Studi Kasus Inkubator Bisnis IPB. Jurnal Aplikasi Bisnis dan Manajemen. 4: 96.

Sumarwan, Ujang \& Hasbullah, Rokhani. 2017. Faktor-Faktor yang Memengaruhi Kinerja dan Kepuasan Tenan di Inkubator Bisnis IPB. Jurnal Manajemen Pengembangan Industri Kecil Menengah. 12: 84-92.

Yuana, Suci Lestari, Azizah, Nur \& Apriliyanti, Indri Dwi. 2016. Komparasi Efektivitas dan Model Governance Inkubator Bisnis Digital antara Pengelola Pemerintah, BUMN, Swasta, Komunitas, dan Universitas. Jurnal Ilmu Sosial dan Ilmu Politik. 20: 133-146. 